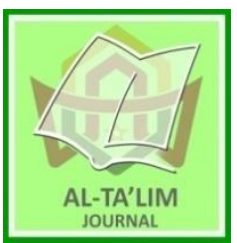

AL-TA'LIM JOURNAL, 28 (1), 2021, (26-34)

(Print ISSN 1410-7546 Online ISSN 2355-7893)

Available online at http://journal.tarbiyahiainib.ac.id/index.php/attalim

\title{
Message Design of Printed and Digital Material to Meaningful Learning
}

Received: 05 ${ }^{\text {th }}$ July 2020 Revised: 07 th February 2021; Accepted: $28^{\text {th }}$ February 2021

Permalink/DOI: $\underline{\text { http://dx.doi.org/10.15548/it.v28i1.634 }}$

\section{Ulfia Rahmi}

Universitas Negeri Padang, Indonesia.

E-Mail: ulfia@fip.unp.ac.id

\author{
Azrul \\ Universitas Islam Negeri Imam Bonjol \\ Padang, Indonesia \\ E-Mail: azrulmardin@unp.ac.id
}

\begin{abstract}
This article reports on research a message design of printed and digital message in Learning Theory course at Universitas Negeri Padang (UNP). Survey was conducted to collect data on the utilization of instructional materials by students who ware active in the semester in January-June. The results indicated that the print instructional materials written by lecturers have started to consider the design principles message, but still needs to be improved. That principle has not been carried out for digital teaching materials. Digital teaching materials need to be developed to familiarize students studying in 21 st century environments by optimizing the campus e-learning facility to be able to perform generative learning, and meaningful learning.
\end{abstract}

Keywords: Message Design; teaching materials; teaching and learning theories; print and digital materials.

How to Cite: Rahmi, U., \& Azrul, A. (2021). Message Design of Printed and Digital Material to Meaningful Learning. Al-Ta lim Journal, 28(1), 26-34. doi:https://doi.org/10.15548/jt.v28i1.634

\section{INTRODUCTION}

Learning in the 21 st century must be adapted to the demands of the students when it plunged into the field. One of the characteristics of the 21 st century learning is learning based on information and communication technology. These advances offer media and learning resources that are broad, accessible, more flexible, and more varied for students. It is urgent to do so that learning messages are designed and developed according to the generation.(Asgar \& Satyanarayana, 2021; Passerini \& Granger, 2000; Sluijsmans, 2012; Xingfu \& Xinyu, 2009) In the first generation, learning messages are stored in the printed instructional materials; the second-generation learning message can be followed through distance education, while the third-generation message is more interactive learning. Interactive message lesson creates a learning experience for the students so that students are able to interpret the message. According to Jacobs (2010); Kay \& Greenhill (2011); Silva (2009), a school or university shall submit to the teaching staff to look at a map of the curriculum and try to find loopholes to integrate technology into the curriculum implementation. The integration of technology into learning, according to Lin \& Chen (2017); Maloney et al. (2013) causes very rapid changes of the material; into digital form so that teachers should be able to adapt to the current situation. That is, advances in information technology and communication bore different forms of learning with previous learning.

The advent of information and communication technology such as computers and the Internet in learning, learning can be done anywhere and anytime. If earlier the learning message delivery in the first 
generation, according to (Boone \& Higgins, 2007), in print form, then because advances in messaging technology can be studied from a distance and can be presented interactively. Optimalization of computer and internet in learning can facilitate the distribution of instructional messages using email, and website have been provided. Sending learning materials through computers and networks

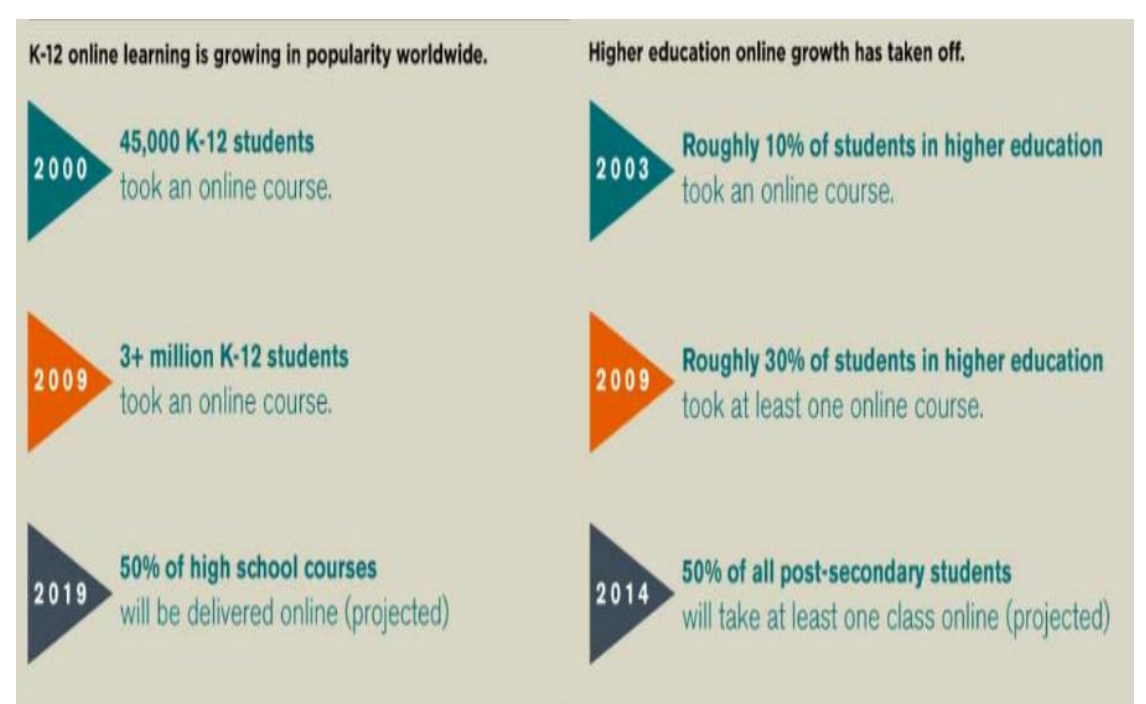

Figure 1. The development of online learning over time

Figure 1 shows that the growth and development of online learning from yearto-year increase. For example, the growth of online college in 2003 just to use online learning resources $10 \%$, but by 2014 had reached $50 \%$. This proves that the very rapid growth of online learning.

Universitas Negeri Padang is one of the universities in Indonesia that facilitate campus community in order to make online learning by providing 24-hour internet service, academic portal, elearning, webmail and college webpage. In this connection, the constraint is the message design course materials, both print and non-print for the optimalization of campus facilities.

The provision of printed and nonprinted materials have not fully used instructional design message principles. Some educators and designers of instructional media as a whole tends to move the material contained in the book into selected media. For example, research by (Ma'mur et al., 2013), just enter print in such as the internet and intranet according Smaldino et al., (2012) known as online learning. In the future no longer possible to circumvent online learning. Christensen et al., (2011); Christensen \& Horn (2008) predict that $50 \%$ of school programs will be delivered through online. Other data showed the future of online learning and development from time to time as shown in the figure 1 .

the teaching materials online in step development of the material, is not designed to follow the design principles message. It was certainly was a big mistake based on the study of design principles for a very different message read someone's endurance power on textbooks and teaching materials than reading website. Taking into account the resistance reading that is very different, need to be designed so that student learning message is easily interpreted the message that learning. The inappropriacy teaching and learning media designer to the presentation of the material in the form of non-print led to learning through non-print materials did not show significant results. It has been proved by Tuncer \& Bahadir (2014) in his research that reading printed material was more efficiently than the reading on a computer screen. According to Lohr \& Kowch (2004) the design of the message is an important component in the learning system but neglected. Therefore, it is a high time to maintain the motivation of learning to read and learning motivation so 
that students are able to complete the reading and interpret the message.

Messages design according to Lin et al. (2015), is the process of manipulating or planned manipulation of symbols that provide the conditions for learning. Design messages need to be rebuilt because the views are narrowed since the 1990s. A narrow view of message design has focused on the knowledge transmission, while the 21 century enables the students to construct their knowledge. This means, message design requires a shift of philosophy. This means that the philosophy that has been understood so far must also change following the 21stcentury education paradigm. namely constructivism. Interest constructivist learning is to solve the problem, the highorder thinking skills and collaborative work. In the view of constructivism, learning is equated with making meaning from experience has already existed, because, experience gained in solving a problem in the past will help solve other problems in the future, both in problemsolving which is almost the same or a new one altogether (Ansyar, 2015). LarsenFreeman (2013) called it the transfer of learning, that is, when a person applying its experience and knowledge to study or solve problems in new situations. On the future of students in need of how to process information and solve problems based on the development of computers. Thus, constructivist learning the nuances needed to build the knowledge and experience of the learners so that they are able to transfer to learn, solve problems, high-order thinking skills and work together.

In addition to the historical and philosophical foundation, the design of the message also based on psychological grounding. According to Braunstein \& Zecchina (2006), the design principle of principles learning message consists of motivation, perception, psychomotor, learning, concept learning, problem solving and the development of attitudes. All of these principles move from a psychological grounding. Psychology can't tell the teacher what to do, but it gives them the principles that will be used to make good decisions and language to discuss their experiences and thoughts (Slavin, 2006). The decision refers to what is meant Ornstein and Hunkins (2013) that psychology includes questions about how students learn and contribute to the learning. And so according Ansyar (2015) by grounding psychology educators are capable of designing, implementing and evaluating learning how the best. Thus, the basis of psychology is very closely related to instructional message design principles to develop the potential of students through the provision of activities and learning experiences in the learning process.

Furthermore, according to Ross et al. (2011), the function of learning message include, a) helping students get the message, b) helping students process the content of the message, c) helping students connect construct a new structure prior knowledge, and d) ensure messages are delivered has the desired effect (Bishop, 2014). The function is to be a way to help students interpret the message of learning and one of the reasons why the design of learning message needs to be considered in designing learning. This means that the message or the content of learning becomes a tool and as a target for instructional designers.

Paivio \& Clark (2006) conducted an investigation on the impact of the use of teaching materials teaching materials colored with black and white. ANOVA analysis is done to the student learning outcomes, found that student learning outcomes using colored teaching materials is higher than in the use of teaching materials in black and white. Feinberg \& Murphy (2000) comparing the attention of students learn to use teaching materials that explain the narrative in the form of texts and teaching materials that include 
tables and graphs. Research shows that with the tables and graphs can hold the attention of students in learning. Two of these studies discuss the design of a message from the media attributes of learning, but there is another side that is also considered in designing the learning message. Referring to the principle message design, namely the principles of motivation, perception, psychomotor, learning, learning concepts to solve problems and change the attitude of the research design learning message needs to variations in the presentation materials, relevance, level of challenge, benefits, positive impression, the legibility of teaching materials, the illustrations in teaching materials, processing of perception, interpretation, psychomotor process, organizing concepts, problem solving and change attitudes.

Based on the urgency of message design learning and previous research indicates there are problems in designing the message, the author conducted research on message design course materials, both printed and non-printed on the subjects Learning Theory at the Department of Educational Technology Universitas Negeri Padang. The purpose of this study was to determine and explain how to design learning message applied to the course.

\section{METHOD}

This study investigates the use and assessment of students to instructional materials subject learning theory of print and digital materials. This study surveyed all students in the Educational Technology study program, Universitas Negeri Padang in the even semester. Students who enroll in the Learning Theory course are asked to fill in valid and realistic instruments. The instrument measures the application of the principles of message design in instructional materials used by the student, which consists of the principles of motivation, reaction, psychomotor, learning, learning concepts, problem solving and change attitudes. Data were analyzed using descriptive analysis to inform the student assessment of each application message design principles in teaching materials.

\section{RESULT AND DISCUSSION}

The percentage of votes against the students teaching materials Learning Theory presented in Table 1. This table is based on the design principles of learning message. Based on Table 1, it can be concluded that the principles of instructional message design in the Learning Theory teaching materials have begun to be applied even though they have not always done so. This is indicated by the dominant percentage number sometimes, and rarely. Only $8 \%$ often and $4 \%$ always apply the principles of learning message design. The following are the results of the acquisition of the analysis obtained message design principles.

Table 1. Assessment of Instructional Message Design Principles

\begin{tabular}{lllllll}
\hline No & $\begin{array}{c}\text { Message } \\
\text { Design } \\
\text { Principle }\end{array}$ & Always & Often & $\begin{array}{c}\text { Some } \\
\text { times }\end{array}$ & Rarely & Never \\
\hline 1 & Motivation & 0,04 & 0,138 & 0,50 & 0,317 & 0,00 \\
2 & $\begin{array}{l}\text { Perception } \\
3\end{array}$ & 0,00 & 0,02 & 0,51 & 0,40 & 0,07 \\
$\quad \begin{array}{l}\text { Psychomot } \\
\text { or }\end{array}$ & 0,06 & 0,18 & 0,49 & 0,27 & 0,00 \\
4 & Learning & 0,05 & 0,09 & 0,52 & 0,29 & 0,05 \\
5 & Learning & 0,08 & 0,10 & 0,42 & 0,40 & 0,00 \\
$\quad \begin{array}{l}\text { Concept } \\
6\end{array}$ & $\begin{array}{l}\text { Problem } \\
\quad \text { Solving }\end{array}$ & 0,04 & 0,02 & 0,49 & 0,36 & 0,09 \\
7 & $\begin{array}{l}\text { Change of } \\
\text { Attitude }\end{array}$ & 0,02 & 0,06 & 0,47 & 0,34 & 0,12 \\
Mean & 0,04 & 0,09 & 0,49 & 0,33 & 0,05 \\
\hline
\end{tabular}

\section{Motivation}

Nearly half of the students enrolled in the teaching materials course in the even semester considered that the application of the motivation principle in designing teaching materials had been carried out, although there were a third $(32 \%)$ of students who still stated that it was rare. The element of assessment of the 
application of motivation is viewed from a) the variation in the presentation of teaching materials to increase student curiosity, b) the variations in delivery strategies, c) the relevance of the material to students' prior knowledge, d) the illustrations on teaching materials, e) the presentation of teaching materials from low to higher difficulty level, f) the presents the material attractively, g) uses a standard font and size in teaching materials, and $h$ ) the communicative language. This principle is applied to maintain students' ongoing motivation in studying the material, confirm meaningful material so that students get positive values from the material.

\section{Perception}

Rate application of the principle of perception in teaching materials Learning Theory half $(51 \%)$ of students states sometimes do. However, looking at the percentage of all options, half $(40 \%)$ of the students stated rarely do. That is, not optimal application of the principle of perception in presenting the message of learning, better assessment of students' perceptions of development in every introductory chapter, explain and confirm the material studied in accordance with previous perceptions.

\section{Psychomotor}

In the learning theory course, the application of psychomotor principles in teaching materials is more than the principles of motivation and perception. It is evident from the statement the percentage of students that a small percentage of students $(18 \%)$ are often made. This means that the teaching materials presented already started psychomotor contains principles that requires students to take action or work steps so that students have a learning experience. Ratings principle psychomotor include presenting duties at the end of the chapter on teaching materials for developing writing skills of students and achieve learning outcomes (LO) subjects, teaching materials with specific tasks that are relevant to the material, and the sort of activities on teaching materials so that students are able to learn and to work independently.

\section{Learning}

Most of the students (52\%) stated that the application of learning principles to teaching materials had been carried out. The principle of this study includes consideration of the nature of the student (learner attributes), student characteristics, conveys strategy, organizing the material vertically and horizontally in teaching materials. When these considerations are ignored, the teaching materials are difficult to understand and interpret by students.

\section{Learning Concept}

The principle of learning concepts is rarely applied. This can be seen from the percentage of students' statements that say $42 \%$ sometimes and 40 rarely. This means that the teaching materials have not been able to impart the concept to students. The application of the principle of learning this concept can be identified from the presentation of abstract or concrete material, the fulfillment of prerequisite material before students are asked to understand certain material, relevance to previous student knowledge and presentation of material or concepts that are interrelated between one discussion and another.

\section{Problem Solving}

The application of the problemsolving principle was carried out by presenting the problems that must be solved. This principle helps train students to think scientifically and think logically. Nearly half of the students $(49 \%)$ who 
were given the instrument stated that the problem-solving principle has sometimes been carried out, but $36 \%$ said it was rare. Only $2 \%$ of teaching materials apply problem solving principles. This means that the learning theory teaching materials have not applied the principle of problemsolving optimally. This principle was important to maintain so that students can solve other problems that have the same pattern as the problems they solved in the lecture process.

\section{Change of Attitude}

The application of the principle of a change of attitude is not much different from the application of other principles in designing the learning message. Four students $(6 \%)$ stated that the principle of Change of Attitude was often carried out, but the percentage of the number of students who stated sometimes and rarely was greater, namely $82 \%$ of the students. The difference is very significant. Often dichotomy between a change in attitude by the mastery of learning by the student messages. Indeed, a change in attitude can be inserted in the course material, for example by presenting a message on the material from invited speakers, presenting examples / modeling that can emulate the students, and confirm the mismatches presented examples on teaching materials.

Based on data from these studies, the application of design principles message needs to be improved in the presentation of teaching materials. Taking into account the design functions such as message conveyed by Bishop (2014) earlier, message design to be a way to help students interpret the message of learning and one of the reasons why the design of learning message needs to be considered in designing learning. Referring to Ausubel (2012) learning step can be performed by a) preparing a learning situation, b) selecting appropriate materials for learners and c) to present it in an organized manner, d) avoid rote and more emphasis interpret the material. To realize meaningful learning as it is called Ausubel be designed learning message containing the message design principles because these principles provide students with learning experiences through consideration the needs of students to the material.

Furthermore, designing learning message is very important to avoid overlapping of material and avoid rote learning Slavin (2019). Students need instructional messages which facilitate them to learn, to know how to learn (learn how to learn) and develop themselves through generative learning, discovery learning and independent learning. Students in learning is directed to construct meaning or knowledge (knowledge construction) learning message based on prior knowledge and experience that has been previously owned. This has to do with the opinion of Antonenko et al. (2014), that the message focused on optimizing the design of the communication system of learning by finding the most effective way to help students construct knowledge. While Mayer (2003) reminiscent of the design of the message needs to meet the principles of coherence and cohesion, and considering the sequence of material, both horizontally and vertically. In this connection, Kuboja \& Ngussa (2015) recommends that messages are presented that consider the scope, sequence, integration, articulation and continuity between the material balances. Thus, in developing learning materials need to consider these suggestions for the design of messages that a message can be interpreted, so that the message design does not only serve as an addition to knowledge, but also as a tool to develop themselves students and help them transform themselves from being a copycat message into construction of message.

The discussion of the above teaching materials is not limited to print instructional materials but include nonprint instructional materials therein. Both 
types of instructional materials necessary to consider the design principles messages to help students form a learning experience. The application of these principles is of particular concern when using non-print instructional materials through e-Learning. There is little difference between printing and nonprinting teaching materials, according to Cloud (2010) the implementation of web-based curriculum (non-print) is a combination of engagement and learning message that is relevant to high-quality pedagogy. This means that non-print instructional materials are even more challenging to design lecturer rich learning experiences and challenges students to participate actively. Non-print teaching materials need to be developed to familiarize students studying in 21 century environments by optimizing the campus facilities to be able to perform generative learning, learning the full meaning (Rahmi \& Darmawan, 2018). To develop print and digital messages this can follow the message design model (Rahmi et al., 2017) and some criteria (Nasir et al., 2019) to improve learning outcome (Bentri et al., 2018)

\section{CONCLUSSION RECOMMENDATION}

AND

Design learning message is a way to help students interpret the message of learning because of its function as a) help students get the message, b) help students process the content of the message, c) help students connect construct a new structure prior knowledge, and d) ensure messages are delivered has effect which are desired. Message design functions can be obtained when applying the instructional message design principles into the presentation of teaching materials. Based on the results of research, teaching materials Learning Theory needs to improve the implementation of the principles, such as the principal motivation, perception, psychomotor, learning, learning concepts, problem solving and change attitudes.

\section{REFERENCES}

Ansyar, M. (2015). Kurikulum Hakikat, Fondasi, Desain dan Pengembangan (Cetakan 1). Jakarta: PT. Kencana.

Antonenko, P. D., Lee, B. R., \& Kleinheksel, A. J. (2014). Trends in the crowdfunding of educational technology startups. TechTrends, 58(6), 36-41.

Asgar, A., \& Satyanarayana, R. (2021). An evaluation of faculty development programme on the design and development of self-learning materials for open distance learning. Asian Association of Open Universities Journal.

Ausubel, D. P. (2012). The acquisition and retention of knowledge: A cognitive view. Springer Science \& Business Media.

Bentri, A., Hidayati, A., \& Rahmi, U. (2018). Students absorption of materials through using blended learning in the implementation of curriculum. IJASSH.

Bishop, M. J. (2014). Instructional message design: Past, present, and future relevance. In Handbook of research on educational communications and technology (pp. 373-383). Springer.

Boone, R., \& Higgins, K. (2007). The role of instructional design in assistive technology research and development. Reading Research Quarterly, 42(1), 135-140.

Braunstein, A., \& Zecchina, R. (2006). Learning by message passing in 
networks of discrete synapses. Physical Review Letters, 96(3), 030201 .

Christensen, C. M., \& Horn, M. (2008). Disrupting class: Student-centric education is the future. Retrieved February, 2, 2013.

Christensen, C. M., Horn, M. B., \& Johnson, C. W. (2011). Disrupting class: How disruptive innovation will change the way the world learns (Vol. 1). McGraw-Hill New York.

Cloud, J. P. (2010). Educating for a sustainable future. Curriculum, 21, 168-185.

Feinberg, S., \& Murphy, M. (2000). Applying cognitive load theory to the design of web-based instruction. 18th Annual Conference on Computer Documentation. Ipcc Sigdoc 2000. Technology and Teamwork. Proceedings. IEEE Professional Communication Society International Professional Communication Conference An, 353-360.

Jacobs, H. H. (2010). Upgrading the curriculum: 21st century assessment types and skills. Curriculum, 21, 18-29.

Kay, K., \& Greenhill, V. (2011). Twentyfirst century students need 21st century skills. In Bringing schools into the 21st century (pp. 41-65). Springer.

Kuboja, J. M., \& Ngussa, B. M. (2015). Conceptualizing the place of technology in curriculum formation: A view of the four pillars of curriculum foundations. International Journal of Academic Research in Progressive Education and Development, 4(2), 54-71.
Larsen-Freeman, D. (2013). Transfer of learning transformed. Language Learning, 63, 107-129.

Lin, G., Shen, C., Reid, I., \& Hengel, A. van den. (2015). Deeply learning the messages in message passing inference. ArXiv Preprint ArXiv:1506.02108.

Lin, M.-H., \& Chen, H. (2017). A study of the effects of digital learning on learning motivation and learning outcome. Eurasia Journal of Mathematics, Science and Technology Education, 13(7), 3553-3564.

Lohr, L., \& Kowch, E. (2004). Designing effective instruction. Educational Technology Research and Development, 52(4), 85-90.

Maloney, S., Chamberlain, M., Morrison, S., Kotsanas, G., Keating, J. L., \& Ilic, D. (2013). Health professional learner attitudes and use of digital learning resources. Journal of Medical Internet Research, 15(1), e7.

Ma'mur, M., Warsono, W., \& Suyanto, E. (2013). Pengembangan Model Pembelajaran Blended Learning pada Matakuliah Konsep Teknologi Informasi. Jurnal Teknologi Informasi Komunikasi Pendidikan (Old), 1(4).

Mayer, R. E. (2003). The promise of multimedia learning: Using the same instructional design methods across different media. Learning and Instruction, 13(2), 125-139.

Nasir, M., Yuliani, H., \& Nastiti, L. R. (2019). The Development of Teaching Materials on Integrated Science, Technology, and Religion to Improve College Students' Integrative Knowledge. Al-Ta Lim Journal, 26(2), 121-130. 
Paivio, A., \& Clark, J. M. (2006). Dual coding theory and education. Draft Chapter Presented at the Conference on Pathways to Literacy Achievement for High Poverty Children at The University of Michigan School of Education.

Passerini, K., \& Granger, M. J. (2000). A developmental model for distance learning using the Internet. Computers \& Education, 34(1), 115.

Rahmi, U., \& Darmawan, D. (2018). Blog folio in blended learning: A development of students' information processing skills in digital age. Al-Ta Lim Journal, 25(2), 128-134.

Rahmi, U., Effendi, Z. M., \& Ansyar, M. (2017). The Development of Message-Design Model in Blended Learning. The Asian Journal of Technology Management, 10(1), 1.

Ross, S., Munoz, D., Hebert, M., \& Bagnell, J. A. (2011). Learning message-passing inference machines for structured prediction. CVPR 2011, 2737-2744.
Silva, E. (2009). Measuring skills for 21stcentury learning. Phi Delta Kappan, 90(9), 630-634.

Slavin, R. E. (2019). Educational psychology: Theory and practice.

Sluijsmans, D. (2012). Design and Development of Third Generation Distance Learning Materials: From an Industrial Second Generation Approach Towards Realizing Third Generation Distance. Design Approaches and Tools in Education and Training, 81.

Smaldino, S. E., Lowther, D. L., \& Russell, J. D. (2012). The ASSURE model. Instructional Technology and Media for Learning.

Tuncer, M., \& Bahadir, F. (2014). Effect of Screen Reading and Reading from Printed Out Material on Student Success and Permanency in Introduction to Computer Lesson. Turkish Online Journal of Educational Technology-TOJET, 13(3), 41-49.

Xingfu, D., \& Xinyu, L. (2009). On Integrated Design and Development of Distance Learning Materials [J]. Open Education Research, 3, 19-20. 